\title{
Review
}

\section{Formation Mechanisms and Characteristics of the Marine Nepheloid Layer: A Review}

\author{
Zhuangcai Tian ${ }^{1,2,3, * \mathbb{D}}$, Yang Liu ${ }^{1}$, Xiaojiang Zhang ${ }^{4}$, Yan Zhang ${ }^{5, *} \mathbb{C}$ and Mingwei Zhang ${ }^{1}$ \\ 1 State Key Laboratory for Geomechanics and Deep Underground Engineering, China University of Mining \\ and Technology, Xuzhou 221116, China; 6129@cumt.edu.cn (Y.L.); meiichiyou@gmail.com (M.Z.) \\ 2 Key Laboratory of Coastal Science and Integrated Management, Ministry of Natural Resources, \\ Qingdao 266061, China \\ 3 Laboratory for Marine Geology, Qingdao National Laboratory for Marine Science and Technology, \\ Qingdao 266061, China \\ 4 College of Meteorology and Oceanography, National University of Defense Technology, \\ Changsha 410073, China; xjzhangouc@foxmail.com \\ 5 College of Marine Geosciences, Ocean University of China, Qingdao 266100, China \\ * Correspondence: zhuangcaitian@cumt.edu.cn (Z.T.); zhangyan4850@ouc.edu.cn (Y.Z.)
}

check for updates

Citation: Tian, Z.; Liu, Y.; Zhang, X.; Zhang, Y.; Zhang, M. Formation Mechanisms and Characteristics of the Marine Nepheloid Layer: A Review. Water 2022, 14, 678. https://doi.org/10.3390/ w14050678

Academic Editor: Kevin B. Strychar

Received: 1 December 2021

Accepted: 6 January 2022

Published: 22 February 2022

Publisher's Note: MDPI stays neutral with regard to jurisdictional claims in published maps and institutional affiliations.

Copyright: (C) 2022 by the authors. Licensee MDPI, Basel, Switzerland. This article is an open access article distributed under the terms and conditions of the Creative Commons Attribution (CC BY) license (https:/ / creativecommons.org/licenses/by/ $4.0 /)$.

\begin{abstract}
Marine nepheloid layer is widely distributed in the oceans and marginal seas. The concentration of suspended particles in the nepheloid layer is significantly higher than that of the adjacent layers. Marine nepheloid layers include the surface nepheloid layer (SNL), intermediate nepheloid layer (INL), and bottom nepheloid layer (BNL). As a transport pathway for the particulate matter in the oceans, nepheloid layer is important to the carbon cycle and the source-sink system at the continental margin. This paper focused on the characteristics of the marine nepheloid layer and the mechanism of internal solitary waves that form INL and BNL, providing a reference for further research on the marine ecological environment dynamic process and source-sink system. BNL is formed by suspended seabed sediments with strong currents near the bottom, but the fate of BNL remains unknown. Marine nepheloid layer significantly affects the transportation of materials within the ocean. The transport of sediments by ISWs dramatically affects the formation of deep seabed sedimentary landform. However, the formation process and the transport contribution of INL and BNL are still unclear. The systematic and long-term research on the marine nepheloid layer in the world oceans is still limited.
\end{abstract}

Keywords: marine nepheloid layer; sediment; characteristics; mechanism; internal solitary waves; review

\section{Introduction}

Marine nepheloid layer is a turbid layer containing significantly more suspended particles than the adjacent layers in oceans. The suspended particles may collide and form large falling particle aggregates known as marine snow [1,2]. Although the nepheloid layer continually changes with time and space, it shows certain temporal and spatial stability. A marine nepheloid layer could last a few days to years, with a thickness ranging from meters to kilometers [3,4]. Nepheloid layers include the surface nepheloid layer (SNL), intermediate nepheloid layer (INL), and bottom nepheloid layer (BNL). SNL, caused by biological activities and nearshore river plumes, is mainly located in the upper water. INL is formed by suspended particles spreading along the isopycnic line, and generally appears on the edge of the continental shelf, continental slope, submarine canyons, and seamounts. Sometimes weak INL may appear in the deep sea [5-9]. BNL is formed by resuspension of seabed sediments and is near the seabed. It has been found that the thickness of BNL may exceed $2000 \mathrm{~m}$, which is greater than the bottom mixed layer [3,5,9]. Furthermore, as a widespread anthropogenic mechanism, bottom trawling activities can also generate BNLs and INLs over the continental shelves and slopes $[10,11]$. 
The concentration of suspended particles changes with oceans. The background suspended particle concentrations in the oceans are generally less than $0.005 \mathrm{mg} / \mathrm{L}$ [2]. The turbidity of the marginal seawater is greater than that of the oceans. The concentration of the background suspended particles is between 0.05 and $0.08 \mathrm{mg} / \mathrm{L}$ in the Mediterranean Sea [9] and is $0.08 \mathrm{mg} / \mathrm{L}$ in the Scotian Shelf [12]. It is generally believed that the concentration of the suspended particles in the nepheloid layer exceeds $0.1 \sim 0.5 \mathrm{mg} / \mathrm{L}[2,6]$ in different sea areas and at different depths. Studies reported that the concentration in most sea areas ranges from 0.1 to $3 \mathrm{mg} / \mathrm{L}$ but could reach as high as tens to thousands of $\mathrm{mg} / \mathrm{L}$ near the estuaries [2,5].

Marine nepheloid layer was initially discovered as a near-bottom turbidity layer by Jerlov (1953) using an optical measuring instrument during the Swedish Deep-Sea Expedition [13]. Ewing and Thorndike (1965) first named the near-bottom turbidity layer as the nepheloid layer and pointed out that it is a widespread and permanent phenomenon in oceans [14]. The early measurements of the nepheloid layer were limited to indirect optical parameters or the direct filtered suspended matter [13-15]. Biscaye and Eittreim (1977) first converted the turbidity data of the Atlantic water into the concentration of the suspended particles and divided the water column into surface turbidity layer, clear water layer, and deep-water turbidity layer on the basis of the vertical distribution of turbidity [16].

Marine nepheloid layer has gained great interest. The continental rise in Nova Scotia of Canada is the first systematically studied location. The United States has been performing the High Energy Benthic Boundary Layer Experiment (HEBBLE) here since 1981, which first discovered that the BNL is formed mostly by the abyssal benthic storms transporting the suspended particles upward [17]. Many studies have been carried out on the material composition, cause, migration, flux, and formation mechanism of the nepheloid layer in different sea areas such as the Mediterranean [3,9,16], Atlantic Ocean [18-20], California coast [21], Gulf of Mexico [4], Otsuchi Bay [22], Portugal continental shelf [23], St. Lawrence Bay [24], Central Pacific [25], East China Sea continental shelf [26,27], northern South China Sea [28-32], and the Arctic Ocean [33] (Figure 1). Furthermore, numerical simulations have also been performed [34,35].

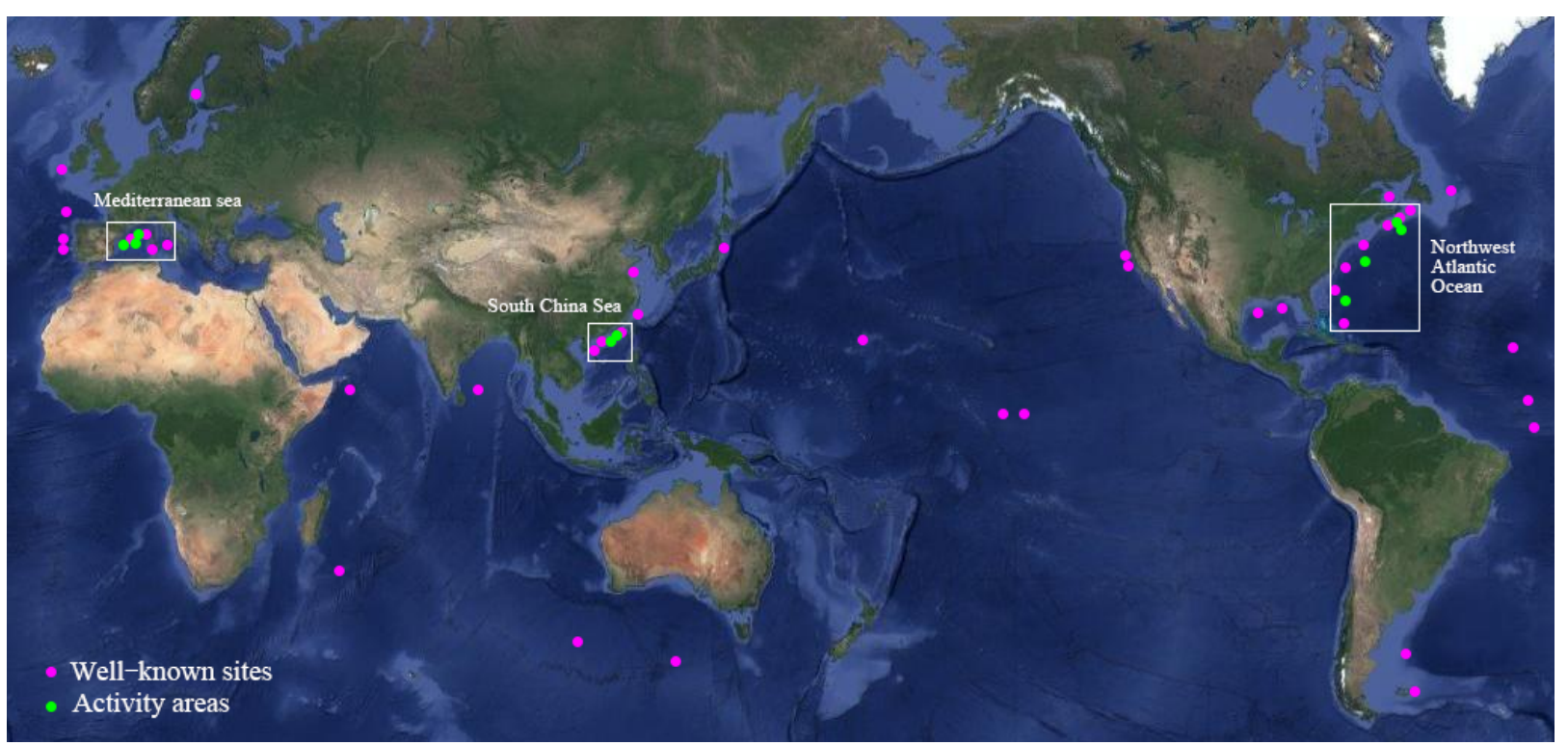

Figure 1. Global marine nepheloid layer distribution. Nepheloid layers observed from 1953 to 2019. Shown are well-known sites of occurrence (pink) and new areas of activity (green).

As the largest carbon pool on the Earth, oceans play an important role in mitigating global warming. The carbon cycle in the marine nepheloid layer, predominantly in the SNL, has various forms, complex processes, and a huge amount of substance. The duration, transfer, and destination of the different carbon forms in the nepheloid layer are important subjects in the study of the sources and sinks of the carbon cycle in the ocean that have 
attracted extensive attention $[25,36]$ such as the Shelf Edge Exchange Processes (SEEP-I, SEEP-II) programs [37] and the Ocean Margin Exchange (OMEX) study on the European margin [38]. As pathways for transporting the terrestrial materials from the edge to the interior of the ocean, the nepheloid layer also accommodates sinking particles and resuspended particles at the bottom of the water column [39]. Lateral transport is the main form of particulate matter transport that is vital to the global marine particulate matter budget $[25,39,40]$. In the nepheloid layer, the lateral particulate matter transport flux is several orders of magnitude larger than the vertical flux. Although occupying only 15 to $20 \%$ of the ocean surface area, the continental shelf and continental slope are vital to the ocean carbon cycle as these portions account for almost half of the primary productivity of the entire ocean [41,42]. Sources of the suspended particles in the nepheloid layer include the surface organisms as well as the resuspension and lateral transport of continental margin seabed sediments [42]. Due to the ubiquitous nepheloid layers, the most organic carbon in the sediments of continental shelves and slopes will be resuspended. Therefore, the nepheloid layer is closely related to the ocean carbon cycle.

Gardner et al. (2018) plotted the global maps of BNL on the basis of 8804 global profiles from 1964 to 2016 [18]. The global maps could benefit the understanding of the deep ocean sediment dynamics, linkage with upper ocean dynamics, and the potential for scavenging adsorption-prone elements near the seafloor as the maps provided a comprehensive comparison of these datasets on a global scale [18]. However, BNLs found in most proportions of the Pacific, Indian, and Atlantic basins away from continental margins that are induced by the internal wave $[22,28,30,31]$ were not included in the maps.

Suspended sediments can act as tracers in contact with water on the edge of the continent $[5,39,43]$. The BNL is a layer directly above the seafloor with relatively high suspended particulate matter, while the INL is in the middle depth with the peak suspended particle concentration. There are enough particles to produce a measurable response in light transmission or backscattering. However, the particle concentration is too small to affect the density, and fine particles can basically be considered as active tracers [39]. In many cases, the INL can be traced along the isopycnic surface to the original depth on the continental slope or shelf.

However, there is still a lack of detailed research and quantitative analysis on the role of the nepheloid layer in the material transport and source-sink processes. It is difficult to capture these temporal and spatial processes. The lack of research is partly attributed to the limited methods and subject categories. The research on internal waves (internal tides, internal solitary wave (ISW)), turbulence, and mixing have always been the task of physical oceanographers and the research on the fate of suspended sediments and other near-margin materials have been carried out by marine geologists and biogeochemists. Internal tides generated by barotropic tides flowing over varying topography are ubiquitous in the oceans [44]. Internal tides could transport significant amounts of energy over hundreds or even thousands of kilometers and behave as the primary driver of diapycnal mixing in the deep ocean. ISWs are remotely generated in the rough topography through energetic tide-topography interaction [44]. Although the generation processes, propagation, and dissipation of ISWs have been discussed, problems about the influence on the nepheloid layer still exist.

\section{Characteristic of Marine Nepheloid Layer}

\subsection{Marine Nepheloid Layer of the Ocean}

Research on the marine nepheloid layer of the ocean has been conducted the most thoroughly as it was first discovered in the ocean. The nepheloid layers in the ocean only include SNLs and BNLs. However, INL only was found in the Atlantic Ocean at depths of 3200 3700 m, which was the result of the Deep Western Boundary Current (DWBC) suspending sediment at depths of $4300 \mathrm{~m}$ [20]. As it is far away from the continental margin, the ocean water is cleaner, and the concentration of suspended matter is smaller. The background concentration of the North Atlantic is $0.02 \sim 0.03 \mathrm{mg} / \mathrm{L}$. The minimum 
concentration of the water profile is one to two orders of magnitude lower than that of the SNL [16]. The concentration of suspended matter in the nepheloid layer lasting several weeks to months is generally above $0.30 \mathrm{mg} / \mathrm{L}[3,45]$. Most particles in the BNL are fine silt to clay with average particle size of less than $8 \mu \mathrm{m}$.

Eittreim et al. (1976) mapped the spatial variability of BNL in the Atlantic Ocean with the turbidity data through 12 years and found that the concentration of near-bottom particulate matter in the Northwest Atlantic Basin changed 70 times in space [46]. The highest concentration was located near the western edge of the basin (Figure 2). Eittreim et al. (1976) believed that the strong nepheloid layer at the edge was caused by DWBC, namely, the southward flow of cold deep water eroding seafloor sediments in the high latitudes of the North Atlantic [46]. In fact, the deep-sea bottom water current is dynamic, and the average equatorial geostrophic current such as DWBC velocity of the deep-sea current can reach up to $10 \mathrm{~cm} / \mathrm{s}$ [3]. It was not until the late 1970s and early 1980s that the bottom water velocity and turbidity were measured simultaneously, such as by Johnson et al. (1976) [47]. At $20 \mathrm{~m}$ above the seabed in the northwest of Bermuda, serial measurements recorded the first large and intermittent increase in turbidity [48]. In the HEBBLE project, the term abyssal benthic storm was used to describe an event with a current velocity exceeding $20 \mathrm{~cm} / \mathrm{s}$, and similar events have been intensively studied [17,45,49-51] in the lowermost continental rise of the eastern United States and the Hatteras Abyssal Plain [52], the northeastern Atlantic Ocean [53], and the Argentine Basin [54]. Abyssal benthic storms are similar to sandstorms where the fluid moves fast enough to erode and suspend the sediment and mix the sediment with the overlying fluid, creating a redistributed turbidity layer in the downwind/downstream. Turbidity currents often occurring in submarine canyons can also form BNLs [42]. However, research on the duration and scale of the nepheloid layer is limited, and so is the analysis of how the geological time scale influences the seabed.

The formation of SNLs in the ocean is caused by plankton activities [3]. The suspension, mixing, and vertical transport of nutrients on the seafloor may affect the growth of plankton, which in turn affects the SNL $[55,56]$. However, this idea has not been verified with substantive evidence. Interdisciplinary research by field observations among physical oceans, marine biology, marine geology, etc., is needed.

\subsection{Marine Nepheloid Layer in the Marginal Sea}

Research on the marine nepheloid layer in the marginal sea mainly focused on the Mediterranean [3,8,9,57], the coast of California [21], the Gulf of Mexico [4], the Otsuchi Bay [22], the Portuguese shelf [23,41], St. Lawrence Bay [24], and the East China Sea shelf and northern South China Sea [28-31]. Nepheloid layers in the marginal sea include SNLs, INLs, and BNLs $[5,6,8,42,58]$. The particulate matter in the INL is fine particulate matter that may suspend for months to years before settlement [5]. The INLs have the largest vertical span along the water column and can be divided into shallower and deeper ones. The deeper INL is formed by the diffusion of suspended sediments on the seafloor along the isodensity line, which mainly occurs near the outer shelf, continental slope, submarine canyons, and seamounts [5,6]. Biological factors are the main cause of the formation of the shallower INL [12]. Nepheloid layer in the marginal sea is mainly caused by internal waves, especially internal tides [7,58] suspending seabed sediments $[5,6,8,9,21]$.

Nepheloid layer in the marginal sea is more complex than that in the ocean. The INL and BNL are ubiquitous in the marginal sea, which significantly contributes to the transport of shelf suspended sediment and particulate matter from the ocean margin to the ocean interior $[12,21,39,59]$. INLs are even more significant than the BNL in terms of sediment transport [21]. The number of INLs and the thickness and length of BNLs vary at different marginal seas $[8,22-24,28,59]$ (Table 1 ), which is important to the quantity of suspended sediment transported to the ocean interior with INLs. 


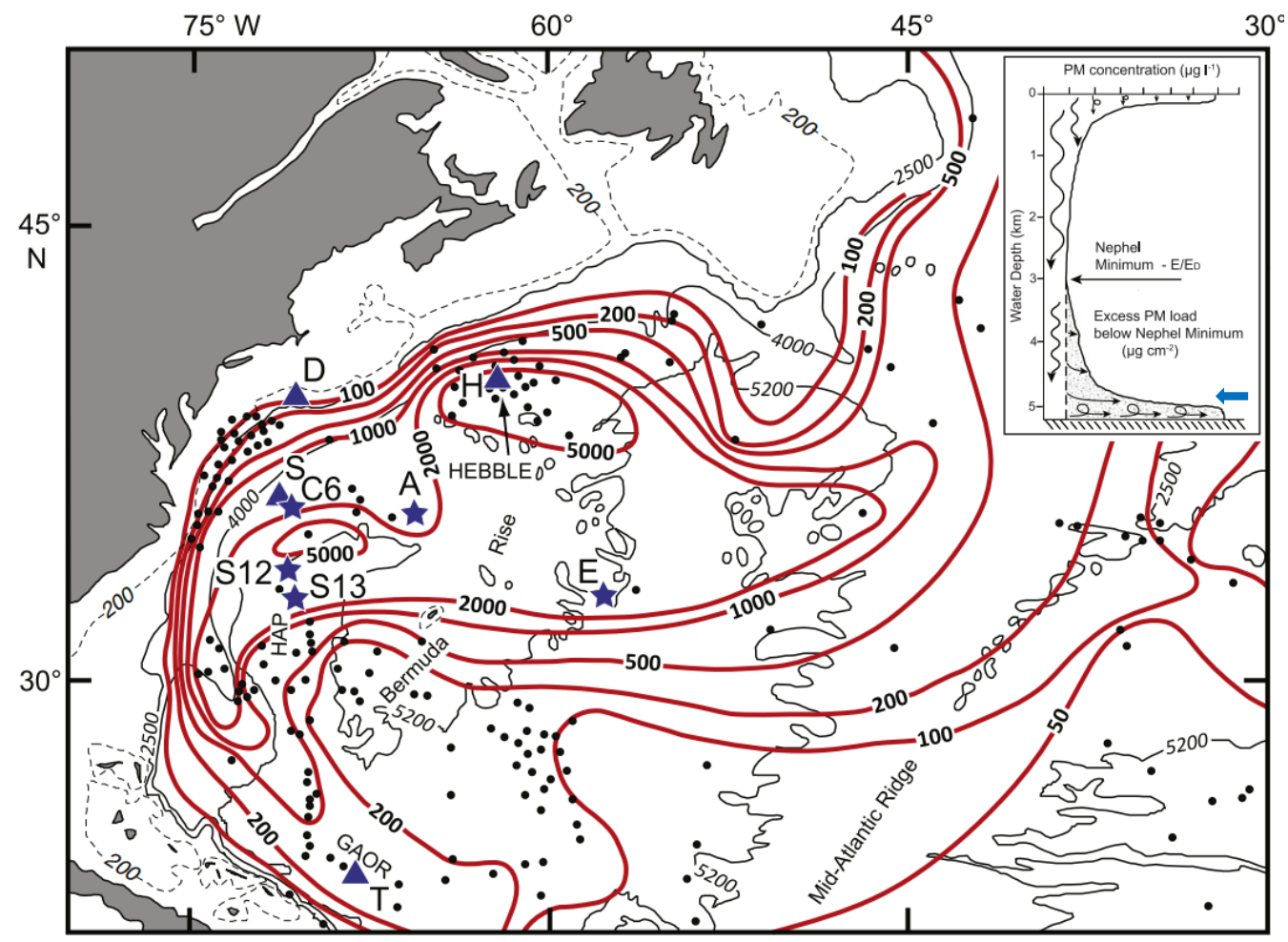

Figure 2. Distribution of excess particulate matter load (red contours, in $\mu \mathrm{g} / \mathrm{cm}^{2}$ ) in the bottom nepheloid layer of the western North Atlantic Ocean, with nephelometer data from the HEBBLE area [55]. Nephelometer profile locations are indicated by dots. Bottom Ocean Monitor (BOM) locations (triangles) and mooring sites (stars) are identified. Black dashed and solid lines are bathymetric contours. The insert shows an idealized nephelometer profile. Looping arrows indicate surface-water and benthic boundary layer mixing. Horizontal arrows indicate lateral transport of resuspended sediment. Wavy vertical arrows indicate particles sinking from surface waters. Blue arrow indicates the DWBC location.

Table 1. Statistics of the nepheloid layers in the marginal sea.

\begin{tabular}{ccccc}
\hline References & Method & Location & $\begin{array}{c}\text { Number of } \\
\text { INLs }\end{array}$ & $\begin{array}{c}\text { Thickness and Length } \\
\text { of the BNLs (m) }\end{array}$ \\
\hline$[59]$ & Field observations & Shetland slope, Scotland & 2 & 100 and 10,000 \\
{$[8]$} & Field observations & Alboran continental slope, Mediterranean & 1 & $>100$ and 600 \\
{$[23]$} & Field observations & Western Portuguese mid-shelf & 0 & $10 \sim 15$ and $>1500$ \\
{$[28]$} & Field observations & Shelf break, South China Sea & 0 & 200 and 20,000 \\
{$[24]$} & Field observations & St. Lawrence Estuary, Canada & 1 & 5 and 400 \\
{$[22]$} & Field observations & Otsuchi Bay, Japan & 1 & 2 and 1000 \\
\hline
\end{tabular}

Since the end of the last century, the temporal and spatial distribution characteristics, as well as formation the mechanisms of nepheloid layer in the Mediterranean, has been fully studied, especially in the northwestern Mediterranean $[3,8,57,60]$ and Guadiaro submarine canyon [8]. The systematic study of the nepheloid layer in the Mediterranean has become an essential reference. The research on nepheloid layers in the other seas are only individual studies, not enough to form systematic knowledge. 


\section{Formation Mechanisms of Marine Nepheloid Layer}

\subsection{Formation Mechanisms of Bottom Nepheloid Layer}

\subsubsection{Bottom Boundary Mixing Processes}

Ocean dynamics make the fine particles of bottom boundary layers move, transport, deposit, resuspend, and retransport in the cyclical movement. Ocean dynamics, such as ISWs shoaling, could generate strong near-bottom currents and strong turbulent mixing in bottom boundary layers [22,61]. On the basis of the dominant transport mechanisms, the bottom boundary layer can be vertically structured into the turbulent boundary layer, the viscous sublayer, and the diffusive sublayer [62]. Resuspension is believed to occur due to the shear and global instability in bottom boundary layer including a jet in the adverse pressure gradient region beneath the ISW [61,63,64]. Global instability beneath ISWs depends upon the background flow characteristics, wave amplitude, and Reynolds number [64]. The bottom shear stress induced by ISWs is sufficient to mobilize sediment within the bottom boundary layer [65]. Bottom boundary layer has an important influence on the dynamic processes of the seabed, such as the material exchange between the seabed and the seawater, erosion of seabed sediments, resuspension, and accumulation.

For the typical oceanic density stratification, consisting of a thin upper mixed layer above a thicker benthic zone, ISWs are waves of depression generated offshore [66]. ISWs may interact slowly with a flat bottom or more quickly with local topography. When shoaling into shallower water, ISWs form waves of elevation at the turning point that degenerate into boluses of dense water propagating upslope along the bed [44,61]. The detailed mechanisms of interaction between ISW and bottom boundary layer have been categorized by Boegman and Stastna (2019), which lead to sediment resuspension into those originating from ISWs of depression, ISWs of elevation, and ISW interaction with topography [61].

\subsubsection{Formation Mechanisms}

The BNL is formed from seabed sediments suspended by strong currents near the bottom, mainly caused by seabed storms $[5,9,17,18]$, vortex [18,43], and internal waves $[5,6,8,9]$. The salient feature of the water column near the seabed in most oceans includes the substantial increase in light scattering and attenuation due to increased particulate matter. The HEBBLE conducted in the 1980s confirmed that the BNL of the deep ocean is formed by suspended seabed sediments from deep-sea currents, which is widely found in other sea areas $[5,9,17,18]$. The water flow near the submarine canyon also suspends the sediments, forming the BNL [67]. Subsequently, the phenomenon of vortex forming BNL at the bottom of the continental shelf was first discovered in the northern California shelf [43].

At present, many studies conclude that internal waves, especially ISWs, are the main driving force for the formation of the BNL in the continental shelf and continental slope as the seabed slope of the continental shelf or continental slope is consistent with the internal wave group velocity vector angle, which increases the seabed velocity $[5-9,58,68]$. The formation of the BNL induced by internal waves has also been widely observed in the field [22-24,28,59] (Figure 3) and analyzed with numerical simulation [34,35].

Studies have found that the thickness of the BNL exceeds that of the bottom mixed layer $[3,5,9]$, which has not been explained yet. The existence and fate of BNL remain unknown, although the process of BNL formation has been clearly understood.

\subsection{Formation Mechanisms of Intermediate Nepheloid Layer}

Existing studies have found that although capable of sediment suspension, surface waves alone cannot form INL $[12,21,69]$. Due to stratified water columns, internal waves, especially ISWs, could form INL. Many studies on INL have put forward several opinions, mainly related to the reflection of internal waves. Interaction between internal waves and the critical area of the slope of the seabed are the main reasons for the formation of INL [12,39]. 


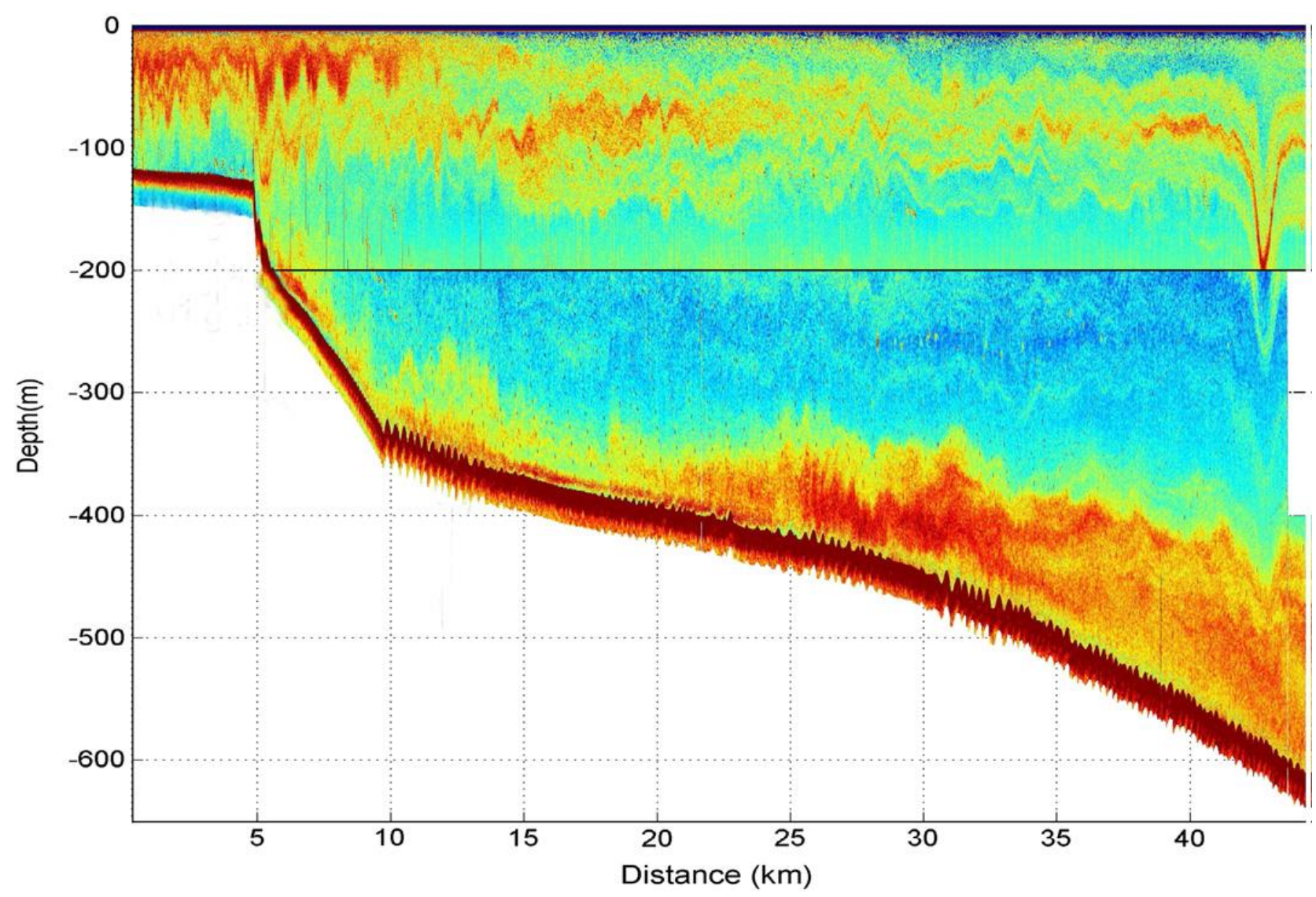

Figure 3. Internal solitary waves resuspended the seabed sediment and formed BNL nearly $200 \mathrm{~m}$ in the northern South China Sea [28].

\subsubsection{Reflection Characteristics of Internal Solitary Wave}

Numerous in situ measurements and remote sensing observations reveal that ISWs are ubiquitous phenomena in density stratified fluids and are commonly observed in the coastal oceans, lakes, and straits [70,71]. ISWs produce shear instability and turbulent mixing that contribute to the global energy transport and dissipation in the world's oceans. ISWs are also important due to the impacts on offshore engineering, biological activity, and military applications such as submarine navigation and underwater acoustic propagation. The velocity field caused by ISWs is a typical feature of translational waves. This fundamental difference means that ISWs transmit energy (mass and heat) during the propagation phase [72,73]. ISWs develop inside the stratified water column, whose stratification is manifested in the rapid increase of the density with temperature or salinity changes. In the ocean, well-mixed surface waters in mid-latitudes are affected by seasonal temperature changes [74-76]). The boundary between the mixed and deep layers is called the thermocline (pycnocline), representing a very stable area that acts as a barrier to the surface process of the ocean. The salinity or temperature changes under the thermocline are very small. The thickness of the mixed layer ranges from 30 to $200 \mathrm{~m}$, mainly depending on seasonal changes [73].

According to the wave reflection theory, the shallowing area of ISWs can be divided into propagation (transmissive) zone, critical zone, and reflection (supercritical) zone $[77,78]$ on the basis of the wave group velocity vector angle $(\alpha)$ and the seabed slope $(\gamma)$ (Figure 4$)$. Puig et al. (2004) [8] have redefined the velocity vector angle $(\alpha)$ of the internal waves group relative to the horizontal plane as follows:

$$
\alpha=\arctan \left[\left(\frac{\sigma^{2}-f^{2}}{N^{2}-\sigma^{2}}\right)^{1 / 2}\right]
$$


where $\sigma$ is the internal wave frequency, $f$ is the local inertial frequency (depending on latitude), and $N$ is the buoyancy frequency or Brünt-Vaisala frequency.

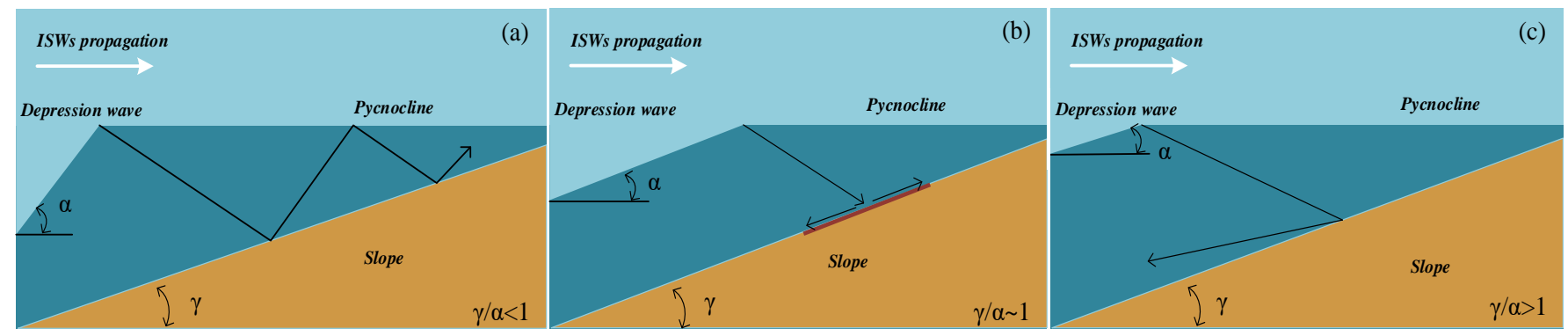

Figure 4. Reflection of internal solitary wave characteristics over slope (see references $[7,8]$ for details about this particular event). (a) Transmissive regions $(\gamma / \alpha<1)$, (b) critical regions $(\gamma / \alpha \sim 1)$, and (c) reflective regions $(\gamma / \alpha>1)$.

Cacchione et al. (2002) first linked the behavior of internal waves close to the slope seabed boundary with sediment resuspension [7]. Moreover, they proposed that internal waves suspending seafloor sediments affecting particle deposition and the distribution of INL and BNL is related to the slope of the seabed. In the propagation zone (transmissive, $\gamma / \alpha<1)$, the ISW energy propagates to the shore, and the energy mainly propagates between the seabed and the boundary layer. In the critical zone (critical, $\gamma / \alpha \sim 1$ ), ISWs enhance the bottom shear velocity, inhibit the redeposition of fine suspended sediments, and erode the seafloor surface sediments [7]. In the reflection zone (supercritical, $\gamma / \alpha>1$ ), most ISW energy will be reflected back into the interior of the ocean.

\subsubsection{Formation Mechanisms of Intermediate Nepheloid Layer by Internal Solitary Wave}

ISWs are the main reason for the formation of INL $[12,39]$. In terms of sediment transport, the INL is even more effective than the BNL [21]. Field observations have proved that ISWs can induce strong vertical flow velocity and pump near-bottom suspended sediments to form $\mathrm{BNL}$ or INL $[21,23,58]$. Studies have suggested that the formation process of INL is related to the internal bore caused by shallowing ISWs $[21,35]$. ISW suspends fine-grained sediments with the vertical velocity to form INL along the pycnocline [35] (Figure 5).
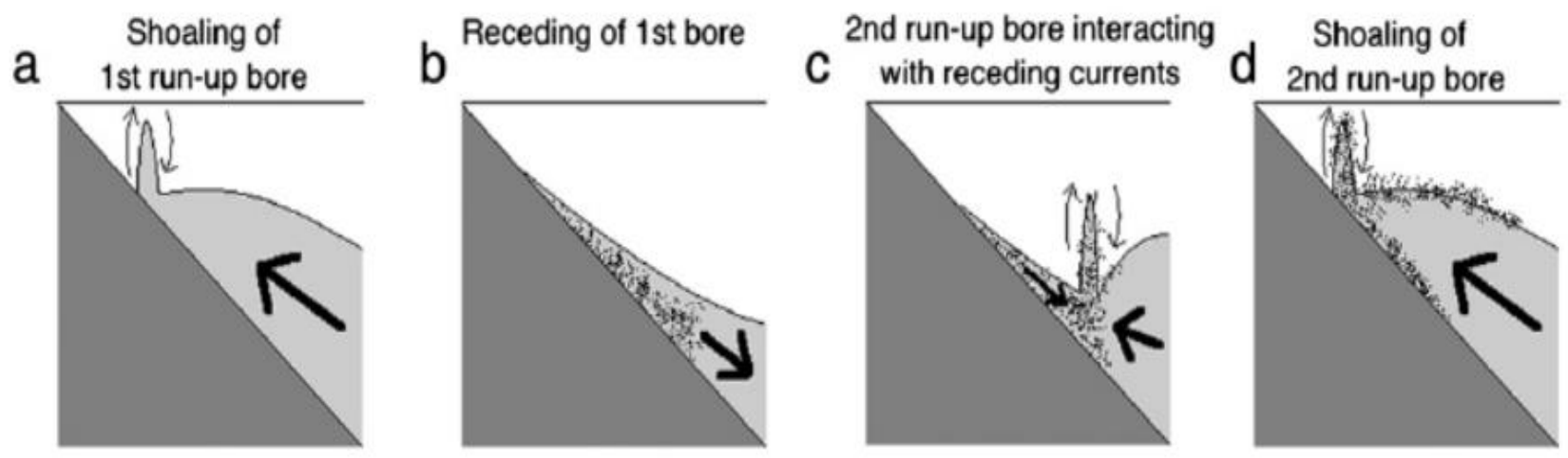

Figure 5. Schematic image of sediment resuspension induced by internal bores [35].

The spreading mode of suspended sediments is another idea about the mechanism of shallowing ISWs forming INL. The ISWs shoal with the submarine slope, which suspends the seabed sediments. Garrett (1990) proposed the concept of boundary layer mixing on the submarine slope on the basis of experiment and theoretical research [79] (Figure 6). In the case of uniform background stratification, Garrett (1990) believed that in the nearmixed layer, near-boundary turbulence only mixes the mixed fluid while not promoting the net vertical buoyant flux or transportation of sediment to the ocean basin [79]. It is 
also believed that the buoyancy generated by ISWs drives the upslope flow closest to the boundary and the downslope flow to somewhere above a certain height $[39,79,80]$ as the bottom mixing causes the pycnocline to be perpendicular to the submarine slope, satisfying the no-flux condition at the boundary. The buoyancy drive does not mean any boundary layer separation or mass exchange between the boundary layer and the interior [81]. However, if the stratification of the water column is no longer uniform, and the local maximum density gradient (thermocline) intersects the submarine slope at a certain depth, the buoyancy along the slope will be sheared out from the pycnocline in the intersection (Figure $6 \mathrm{~b}$ ). The resulting buoyancy-flux convection will cause the mixed fluid to slowly diffuse away from the boundary and spread into the ocean along the isobath $[39,80]$. This mixing mode of the water column is precisely the spreading mode of suspending seabed sediments by ISWs. Studies have found that the thickness of INL can exceed that of the pycnocline layer [34], which has not been proven yet. More research is needed on the formation mechanism of INL by ISWs.

\section{(a) Uniform stratification}
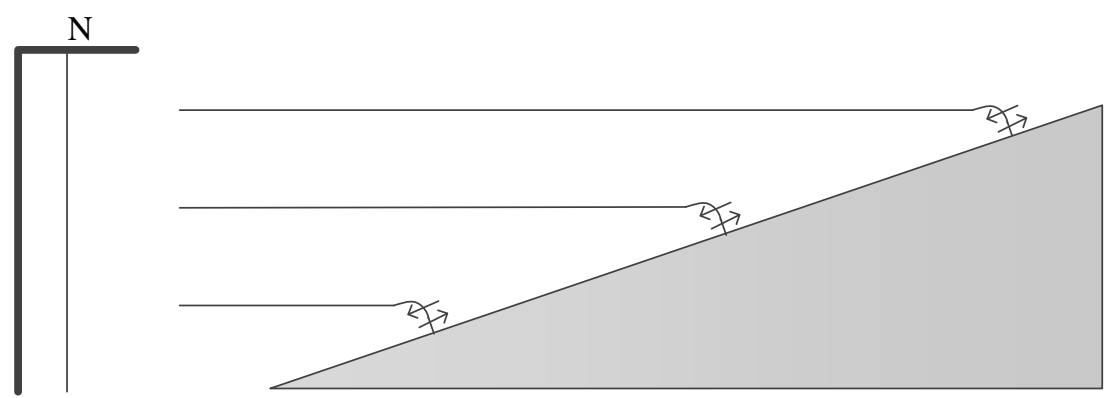

(b) Depth-varying stratification
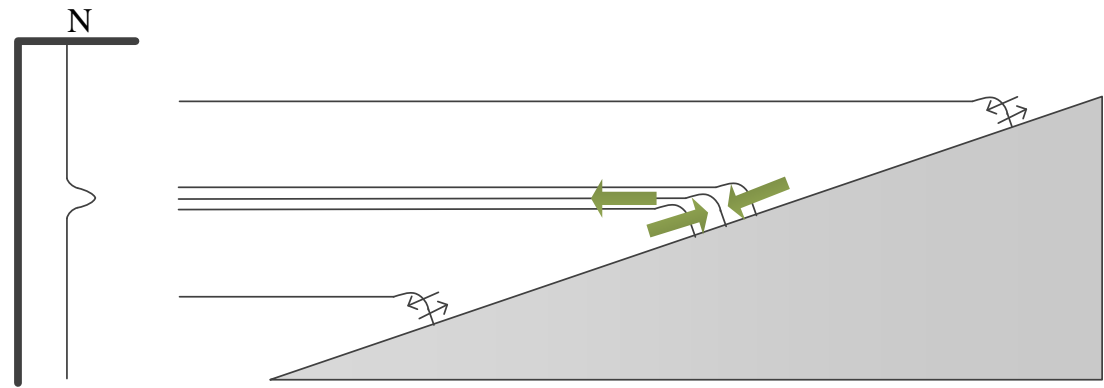

Figure 6. Development of boundary layer flows when mixing in a stratified fluid is confined to a mixing layer above a sloping boundary [39]. (a) Uniform stratification; (b) stratification varies with depth and a pycnocline intersects the sloping boundary. Thin arrows are isopycnals to spread in this region. Thick arrows indicate that convergence pushes mixed fluid out of the boundary layer and the mixed fluids spreading along the pycnocline.

Field experiments have confirmed that the ISWs suspend and transport sediments in two processes. First, the vortex generated by shoaling ISWs suspends the sediments and moves upward through the isopycnals to the shore. The coarse suspended matter redeposits and forms sand waves. Second, the fine suspended matter migrates into the sea through INL and BNL along the thermocline [22,59] (Figure 7). Numerical simulations have found that shoaling ISWs will erode, suspend, and transport mud-like sediments into the sea through the INL and BNL [34]. The shoaling ISWs may be an important mechanism for the spread of the sediment along the continental shelf and transport of the sediment down the slope $[22,34,59,69,82]$. Tian et al. (2019) found that the number of BNLs and INLs was principally determined by the relationship between the angle of the ISW group velocity vector $(\alpha)$ and the slope gradients $(\gamma)$ and proposed a prediction model [31] (Figure 7). ISWs 
suspended seabed sediment by the horizontal velocity in the vortex, and the near-bottom vertical velocity lifted sediment into the water column to create a BNL, which detached from the slope and diffused along the isopycnals, forming more than one INL $[31,83]$. In transmissive regions $(\gamma / \alpha<1)$, one BNL and more than one INL were formed. In critical regions $(\gamma / \alpha \sim 1)$, only one BNL and no more than one INL were observed. In reflective regions $(\gamma / \alpha>1)$, less than one BNL and no INL were formed [31].

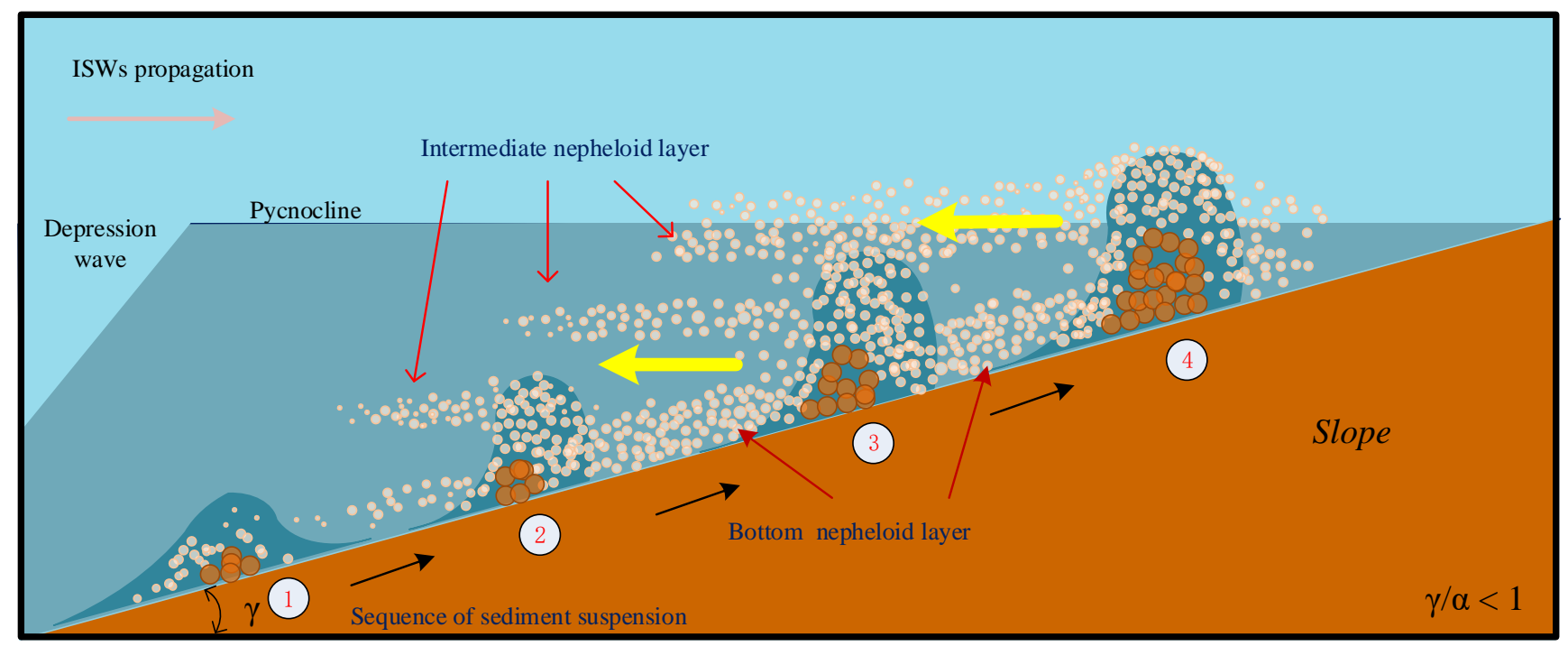

Figure 7. Schematic diagram of the bottom and intermediate nepheloid layers formed by shoaling internal solitary waves in transmissive regions [31]. The sediment resuspended from left to right.

\subsection{Formation Mechanisms of Surface Nepheloid Layer}

The SNL appears in the surface water or subsurface water over the shelf and slope $[30,84,85]$. The SNL related to river plumes extending over the coastal area [86] is an important delivery mechanism of terrigenous sediment from the continental margin to deep waters [84]. Biological particles also contribute to the formation of SNL, especially in spring $[16,41,87,88]$.

Satellite imagery and in situ observations show that the river plume responds rapidly to the alongshore wind, moving predominantly in the wind direction with a weak Ekman drift [89]. The dispersal of river plume is also determined by the turbulent mixing by the wind field in the upper part of the water column and by tidal forces in the lower part [90-92]. As rivers form sediment plume, this effect is particularly apparent during the flood season, then SNL transporting sediments from the continental shelf to the deep waters. In 1983, spring and storm runoff to the Nemadji River produced a surface turbidity plume that extended $10 \mathrm{~km}$ into the lake [93].

The suspended particles in the SNL accommodate microorganisms and some plankton. These organisms affect the aggregation and dispersion of particles in turn, thereby affecting the formation and distribution of the SNL [87]. Oliveira et al. (2002) investigated the SNL dynamics in the northern Portuguese shelf and found that biological particles mainly contribute to the SNL in spring, which is separated from the BNL by a clear water zone, and the particles in the SNL disperse offshore [41]. Moreover, the SNL is restricted to the inner shelf with high inputs of fluvial particles in winter [41].

\section{Observational, Experimental, and Numerical Results}

\subsection{Observation Methods of Marine Nepheloid Layer}

The early observation of the marine nepheloid layer was limited to the indirect measurement of optical parameters or the direct measurement of filtered suspended matter [13-15]. Nowadays, the marine nepheloid layer in the cruises can be measured with the turbidity sensors $[6,9,32]$. The turbidity sensors or nephelometer measurements were either 
transmissometers (Sea Tech Inc. and WET Labs C-Star) or optical backscatter sensors (Seapoint) combined with CTD. However, these methods are only adoptable to a single point or single profile. The profiles of the nepheloid layer can also be observed with an Acoustic Doppler Current Profiler (ADCP) or a multi-beam bathymetry system [18,21,22,28].

Nowadays, more methods have been adopted to observe the nepheloid layer. On the southern continental shelf of Monterey Bay, autonomous underwater vehicles (AUVs) were employed to collect the temperature, salinity, and pressure data measured with a Neil Brown G-CTD, as well as chlorophyll-a concentration and optical volume scattering measured with a WET Labs ECO Puck triplet sensor [21].

In the northern South China Sea, the seismic oceanography method was adopted to measure the nepheloid layer on the shelf and upper continental slope [94] (Figure 8). Geng et al. (2018) found that the nepheloid layer is indicated by the enhanced reflections on the seismic oceanography profiles [94]. With the seismic oceanography method, the characteristics and profile of the nepheloid layer were observed in addition to the seafloor and ISWs.

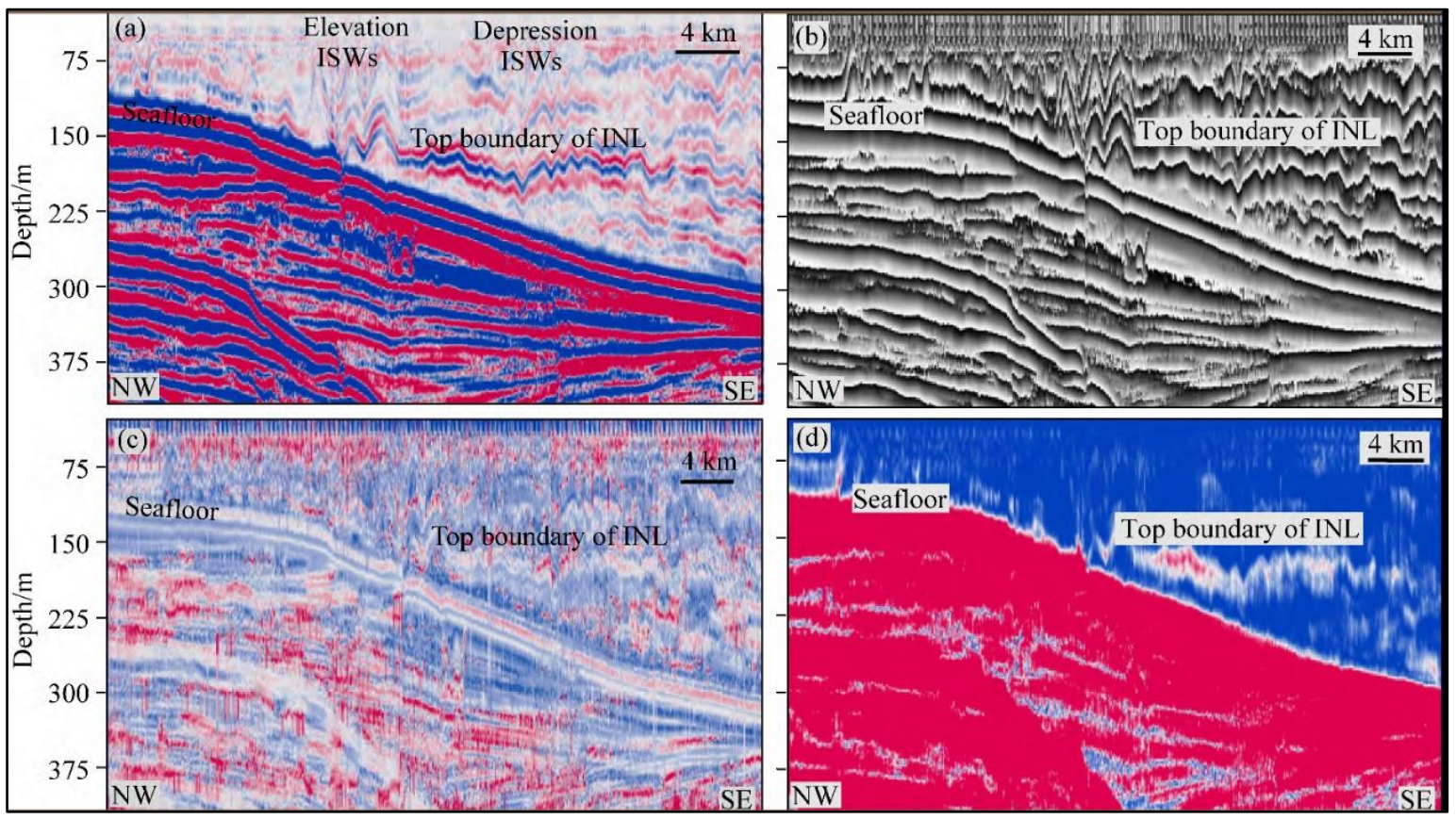

Figure 8. The seismic oceanography (a), instantaneous phase (b), frequency (c), and amplitude (d) profiles of the intermediate nepheloid layer [94]. ISW: internal solitary wave.

Compared to traditional acoustic and optical methods, the seismic oceanography method maps the whole water column structure quickly with high resolution. The method can also capture the temporal and spatial variations in the nepheloid layers and realize the four-dimensional observations.

\subsection{Laboratory Experiments and Numerical Simulation on Nepheloid Layer}

There is a lack of laboratory experiments and numerical simulations, which are useful for the visualization and investigations under ideal conditions of the nepheloid layer. Helfrich (1992) found a BNL induced by shoaling ISW in a two-layer system on a uniform slope on the basis of laboratory experiments [95]. Several laboratories [96-98] have shown that intrusions of mixed fluid after ISW breaking on slopes drive offshore transport along the pycnocline. More recently, Tian et al. (2019a) studied the INL and BNL caused by ISWs in the flume experiments (Figure 9) and found that the maximum height of the suspended sediment is the height of the pycnocline [83]. The suspended sediment may be slightly transported up to the top of the slope via the BNL [83]. Tian et al. (2019a) analyzed the detailed formation processes of INL and BNL caused by ISWs and found 
that ISWs suspended seabed sediment by the horizontal velocity in the vortex [83]. The near-bottom vertical velocity lifted sediment into the water column to create a BNL, which detached from the slope and diffused along the isopycnals, forming more than one INL [83]. Furthermore, the shearing stresses of ISWs was proved to be larger than the maximum critical shearing stress of sediment [99]. However, the flume experiments are small-scale, and therefore not adaptable to the study of the natural oceans.

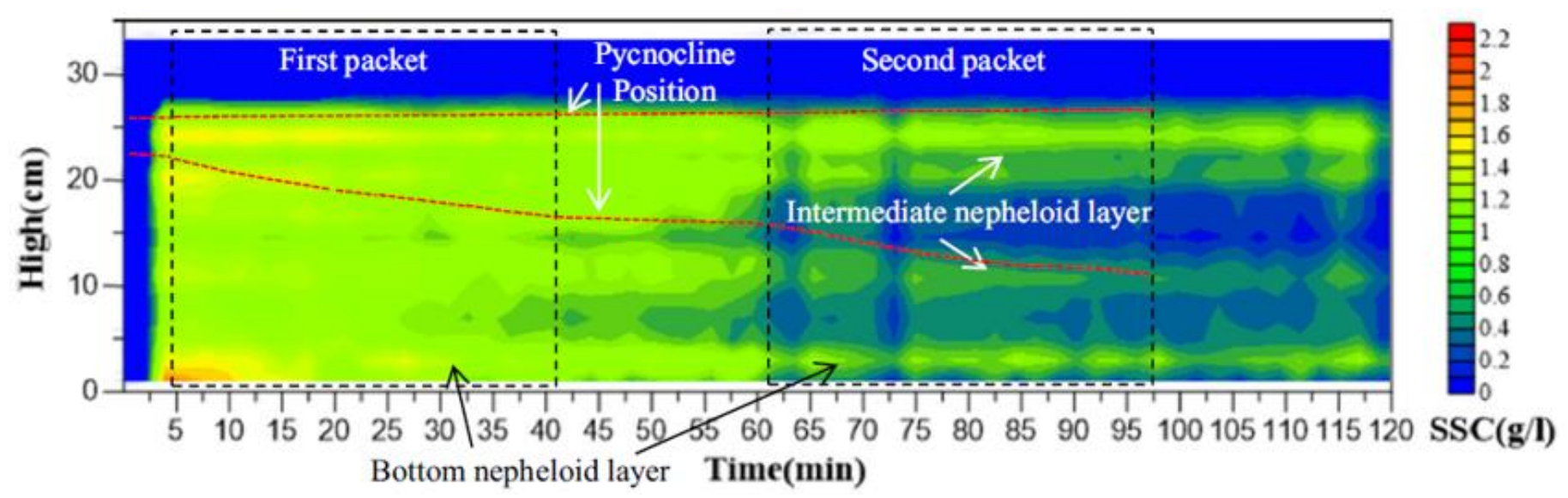

Figure 9. Time series of the suspended sediment concentration (SSC) profile of clayey silt beneath the high-frequency internal solitary wave packet [83]. The black dashed square indicated the time with internal solitary wave packets. The red dashed line above indicated the initial pycnocline position and the line below indicated the real pycnocline position.

There are numerical simulations to examine the resuspension, dispersal, and transport induced by ISW breaking on slopes [22,34,98,100]. Bourgault et al. (2014) adopted twodimensional, nonlinear, and nonhydrostatic field-scale numerical simulations to examine the resuspension, dispersal, and transport of mud-like sediment caused by the shoaling and breaking of long ISWs on uniform slopes [34]. Masunaga et al. (2015) adopted the nonlinear and nonhydrostatic SUNTANS model in a two-dimensional domain to reproduce the observation results of the sediment resuspension caused by the ISWs in a shallow bay [22]. It was found that the INL and BNL were formed by ISWs. Arthor and Fringer (2016) innovatively employed the results of a direct numerical simulation (DNS) with a particletracking model to investigate the three-dimensional transport by ISW on slopes and found that the offshore transport occurred due to an intrusion of mixed fluid that propagated offshore and forming resembles an INL [100]. The onshore and offshore transport and lateral turbulent diffusivity values were also calculated [100]. In the future, numerical simulations could be one of the main methods to study the nepheloid layer in the ocean due to the simulation on the true scale.

\section{Summary and Future Outlook}

Marine nepheloid layer, connecting the continental margins and the interior of the ocean with various forms and complex processes, is important for material transportation, ocean carbon cycles, and the study on the source-sink systems of the ocean. This article focused on the characteristics and formation mechanism of the marine nepheloid layer, analyzing the copious previous research and providing a comprehensive understanding of the influence of the marine nepheloid layer.

The systematic and long-term research on the marine nepheloid layer in the world oceans is still limited. Nowadays, more observation methods can be applied to the nepheloid layer. It is necessary to quantitatively analyze the huge impact of the marine nepheloid layer with various methods from a global perspective. 
It is well known that BNL is formed by suspended seabed sediments with strong currents near the bottom, but the fate of BNL remains unknown. Many field observations need to be carried out. The formation mechanism of INL by ISWs also requires further research.

Marine nepheloid layer significantly affects the transportation of materials within the ocean, including vertical and lateral transportation. This transport mode affects surface organisms and seabed sediments, and they also affect each other. At present, the impact and function of marine nepheloid layer are not comprehensively understood. Multidisciplinary research among physical oceanography, marine biology, marine geology, etc., is needed.

The transport of sediments by ISWs dramatically affects the formation of deep seabed sedimentary landform. However, the formation process and the transport contribution of INL and BNL are still unclear. The specific migration distance remains to be studied. Detailed research of the suspended sediments redeposition process both in experiments and field observations is needed. More evidence of the diffusion model of ISW suspending seafloor sediments and the verification of the mechanism of multiple INL is required.

The suspended sediment in marine nepheloid layer could serve as a tracer, which, however, has not been fully utilized. Laboratory experiments and numerical simulations have been carried out, although they are still limited to the nepheloid layer formed by ISWs. Therefore, more field observations should be carried out to analyze the detailed characteristics and various effects of the nepheloid layer.

Author Contributions: Conceptualization, Z.T.; formal analysis, Z.T.; writing-original draft preparation, Z.T.; writing一review and editing, Z.T., Y.L., Y.Z. and X.Z.; supervision, M.Z.; funding acquisition, Z.T. and M.Z. All authors have read and agreed to the published version of the manuscript.

Funding: This research was funded by the Natural Science Foundation of Jiangsu Province (grant no. BK20210527); Open Research Fund of Key Laboratory of Coastal Science and Integrated Management, Ministry of Natural Resources (grant no. 2021COSIMQ002); the National Natural Science Foundation of China (grant no. 42107158); the Fundamental Research Funds for the Central Universities (grant no. 2021QN1096); and the China postdoctoral Science Foundation (grant no. 2018M630635 and 20180059).

Institutional Review Board Statement: Not applicable.

Informed Consent Statement: Not applicable.

Data Availability Statement: The data presented in this study are available on request from the corresponding author.

Acknowledgments: The authors would like to thank the editors and anonymous reviewers for their constructive comments that helped improve the manuscript.

Conflicts of Interest: The authors declare no conflict of interest.

\section{References}

1. Ransom, B.; Shea, K.F.; Burkett, P.J. Comparison of pelagic and nepheloid layer marine snow: Implications for carbon cycling. Mar. Geol. 1998, 150, 39-50. [CrossRef]

2. Wu, Z.; Peng, X.; Wang, H. Formation cause of nepheloid layer and its effect on ocean carbon cycle process. Adv. Mar. Sci. 2004, 22, 364-369. (In Chinese)

3. Madron, X.D.D.; Ramondenc, S.; Berline, L.; Houpert, L.; Bosse, A.; Martini, S.; Guidi, L.; Conan, P.; Curtil, C.; Delsaut, N.; et al Deep sediment resuspension and thick nepheloid layer generation by open-ocean convection. J. Geophys. Res. Ocean. 2017, 122, 2291-2318. [CrossRef]

4. Diercks, A.-R.; Dike, C.; Asper, V.L.; DiMarco, S.F.; Chanton, J.P.; Passow, U. Scales of seafloor sediment resuspension in the northern Gulf of Mexico. Elem. Sci. Anth. 2018, 6, 32. [CrossRef]

5. McCave, I.N. Local and global aspects of the bottom nepheloid layers in the world ocean. Neth. J. Sea Res. 1986, 20, 167-181. [CrossRef]

6. McCave I, N. Nepheloid Layers. Encycl. Ocean. Sci. 2009, 1, 8-18. [CrossRef]

7. Cacchione, D.A.; Pratson, L.F.; Ogston, A.S. The shaping of continental slopes by internal tides. Science 2002, $296,724-727$. [CrossRef]

8. Puig, P.; Palanques, A.; Guillén, J.; El Khatab, M. Role of internal waves in the generation of nepheloid layers on the northwestern Alboran slope: Implications for continental margin shaping. J. Geophys. Res. 2004, 109, 1-11. [CrossRef] 
9. Puig, P.; Greenan, B.J.W.; Li, M.Z.; Prescott, R.H.; Piper, D.J.W. Sediment transport processes at the head of Halibut Canyon, eastern Canada margin: An interplay between internal tides and dense shelf-water cascading. Mar. Geol. 2013, 341, 14-28. [CrossRef]

10. Puig, P.; Martín, J.; Masqué, P.; Palanques, A. Increasing sediment accumulation rates in La Fonera (Palamós) submarine canyon axis and their relationship with bottom trawling activities. Geophys. Res. Lett. 2015, 42, 8106-8113. [CrossRef]

11. Arjona-Camas, M.; Puig, P.; Palanques, A.; Durán, R.; White, M.; Paradis, S.; Emelianov, M. Natural vs. trawling-induced water turbidity and suspended sediment transport variability within the Palamós Canyon (NW Mediterranean). Mar. Geophys. Res. 2021, 42, 38. [CrossRef]

12. Azetsu-Scott, K.; Johnson, B.D.; Petrie, B. An intermittent, intermediate nepheloid layer in Emerald Basin, Scotian Shelf. Cont. Shelf Res. 1995, 15, 281-293. [CrossRef]

13. Jerlov, N.C. Particle distribution in the ocean. Rep. Swed. Deep-Sea Exped. 1953, 3, 73-97.

14. Ewing, M.; Thorndike, E.M. Suspended matter in deep ocean water. Science 1965, 147, 1291-1294. [CrossRef] [PubMed]

15. Biscaye, P.E.; Eittreim, S.L. Variations in benthic boundary layer phenomena: Nepheloid layer in the North American Basin. In Suspended Solids in Water; Gibbs, R.J., Ed.; Plenum Press: New York, NY, USA, 1974; pp. 227-260.

16. Biscaye, P.E.; Eittreim, S.L. Suspended particulate loads and transports in the nepheloid layer of the abyssal Atlantic Ocean. Mar. Geol. 1977, 23, 155-172. [CrossRef]

17. Hollister, C.D.; McCave, I.N. Sedimentation under deep-sea storms. Nature 1984, 309, 220-222. [CrossRef]

18. Gardner, W.D.; Richardson, M.J.; Mishonov, A.V.; Biscaye, P.E. Global comparison of benthic nepheloid layers based on 52 years of nephelometer and transmissometer measurements. Prog. Oceanogr. 2018, 168, 100-111. [CrossRef]

19. Bubnova, E.S.; Kapustina, M.V.; Krechik, V.A.; Sivkov, V.V. Suspended Matter Distribution in the Surface Layer of the East Equatorial Atlantic. Oceanology 2020, 60, 228-235. [CrossRef]

20. Sivkov, V.; Bubnova, E. Distribution of suspended particulate matter at the equatorial transect in the Atlantic Ocean. Ocean Sci. 2021, 17, 1421-1435. [CrossRef]

21. Cheriton, O.M.; McPhee-Shaw, E.E.; Shaw, W.J.; Stanton, T.P.; Bellingham, J.G.; Storlazzi, C.D. Suspended particulate layers and internal waves over the southern Monterey Bay continental shelf: An important control on shelf mud belts?: Suspended Particulate Layers. J. Geophys. Res. Ocean. 2014, 119, 428-444. [CrossRef]

22. Masunaga, E.; Homma, H.; Yamazaki, H.; Fringer, O.B.; Nagai, T.; Kitade, Y.; Okayasu, A. Mixing and sediment resuspension associated with internal bores in a shallow bay. Cont. Shelf Res. 2015, 110, 85-99. [CrossRef]

23. Quaresma, L.S.; Vitorino, J.; Oliveira, A.; da Silva, J. Evidence of sediment resuspension by nonlinear internal waves on the western Portuguese midshelf. Mar. Geol. 2007, 246, 123-143. [CrossRef]

24. Richards, C.; Bourgault, D.; Galbraith, P.S.; Hay, A.; Kelley, D.E. Measurements of shoaling internal waves and turbulence in an estuary: Shoaling Internal Waves And Turbulence. J. Geophys. Res. Ocean. 2013, 118, 273-286. [CrossRef]

25. Yang, Z.; Li, Y. Characteristics of suspended particles in the Pacific Ocean and discussion about near-bottom nepheloid layers Acta Oceanol. Sin. 2007, 29, 74-81. (In Chinese)

26. Qiao, L.L.; Huang, L.L.; Wang, Z.; Yao, Z.; Liu, S. Flux and its seasonal variation of suspended particulate matter in the Bohai Sea, Yellow Sea and East China Sea. Geol. J. 2016, 51, 22-34. [CrossRef]

27. Liu, S.; Qiao, L.; Li, G. Transport and flux of suspended sediment and its seasonal variation over the inner shelf of the east China sea. Oceanol. Limnol. Sin. 2018, 49, 24-39.

28. Reeder, D.B.; Ma, B.B.; Yang, Y.J. Very large subaqueous sand dunes on the upper continental slope in the South China Sea generated by episodic, shoaling deep-water internal solitary waves. Mar. Geol. 2011, 279, 12-18. [CrossRef]

29. Zhang, X.; Chen, J.; Xiang, L.; Fang, J.; Li, D.; Zhu, Y.; Ou, Y.; Fan, Y. A preliminary study on the characteristics of nepheloid layers in the northern South China Sea and their influential factors. Acta Oceanol. Sin. 2014, 36, 51-65. (In Chinese) [CrossRef]

30. Du, X.; Liu, J.T. Particle dynamics of the surface, intermediate, and benthic nepheloid layers under contrasting conditions of summer monsoon and typhoon winds on the boundary between the Taiwan Strait and East China Sea. Prog. Oceanogr. 2017, 156, 130-144. [CrossRef]

31. Tian, Z.; Jia, Y.; Zhang, S.; Zhang, X.; Li, Y.; Guo, X. Bottom and intermediate nepheloid layer induced by shoaling internal solitary waves: Impacts of the angle of the wave group velocity vector and slope gradients. J. Geophys. Res. Ocean. 2019, 124, 5686-5699. [CrossRef]

32. Tian, Z.; Jia, Y.; Chen, J.; Liu, J.P.; Zhang, S.; Ji, C.; Liu, X.; Shan, H.; Shi, X.; Tian, J. Internal solitary waves induced deep-water nepheloid layers and seafloor geomorphic changes on the continental slope of the northern South China Sea. Phys. Fluids 2021, 33, 053312. [CrossRef]

33. Novigatsky, A.N.; Lisitzin, A.P.; Klyuvitkin, A.A.; Shevchenko, V.P.; Kravchishina, M.D.; Politova, N.V. Vertical Fluxes of Suspended Sedimentary Matter in Arctic Sedimentogenesis of Intracontinental Seas. Dokl. Earth Sci. 2018, 479, 384-389. [CrossRef]

34. Bourgault, D.; Morsilli, M.; Richards, C.; Neumeier, U.; Kelley, D.E. Sediment resuspension and nepheloid layers induced by long internal solitary waves shoaling orthogonally on uniform slopes. Cont. Shelf Res. 2014, 72, 21-33. [CrossRef]

35. Masunaga, E.; Arthur, R.S.; Fringer, O.B.; Yamazaki, H. Sediment resuspension and the generation of intermediate nepheloid layers by shoaling internal bores. J. Mar. Syst. 2017, 170, 31-41. [CrossRef] 
36. Weering, T.C.E.V.; Stigter, H.C.D.; Balzer, W.; Epping, E.H.G.; Graf, G.; Hall, I.R.; Helder, W.; Khripounoff, A.; Lohse, L.; McCave, N.I.; et al. Benthic dynamics and carbon fluxes on the NW European continental margin. Deep. Sea Res. Part II Top. Stud. Oceanogr. 2001, 48, 3191-3221. [CrossRef]

37. Biscaye, P.E.; Flagg, C.N.; Falkowski, P.G. The Shelf Edge Exchange Processes experiment, SEEP-II: An introduction to hypotheses, results and conclusions. Deep-Sea Res. II 1994, 41, 231-252. [CrossRef]

38. Wollast, R.; Chou, L. Ocean margin exchange in the northern Gulf of Biscay: OMEX I, an introduction. Deep.-Sea Res. II 2001, 48, 2971-2978. [CrossRef]

39. McPhee-Shaw, E. Boundary-interior exchange: Reviewing the idea that internal-wave mixing enhances lateral dispersal near continental margins. Deep. Sea Res. Part II Top. Stud. Oceanogr. 2006, 53, 42-59. [CrossRef]

40. Liu, Z.; Zhao, Y.; Colin, C.; Stattegger, K.; Wiesner, M.G.; Huh, C.-A.; Zhang, Y.; Li, X.; Sompongchaiyakul, P.; You, C.-F.; et al. Source-to-sink transport processes of fluvial sediments in the South China Sea. Earth-Sci. Rev. 2016, 153, 238-273. [CrossRef]

41. Oliveira, A.; Vitorino, J.; Rodrigues, A.; Jouanneau, J.; Dias, J.; Weber, O. Nepheloid layer dynamics in the northern Portuguese shelf. Prog. Oceanogr. 2002, 52, 195-213. [CrossRef]

42. Puig, P.; de Madron, X.D.; Salat, J.; Schroeder, K.; Martín, J.; Karageorgis, A.P.; Palanques, A.; Roullier, F.; Lopez-Jurado, J.L.; Emelianov, M.; et al. Thick bottom nepheloid layers in the western Mediterranean generated by deep dense shelf water cascading. Prog. Oceanogr. 2013, 111, 1-23. [CrossRef]

43. Washburn, L.; Swenson, M.S.; Largier, J.L.; Kosro, P.M.; Ramp, S.R. Cross-Shelf Sediment Transport by an Anticyclonic Eddy Off Northern California. Science 1993, 261, 1560-1564. [CrossRef] [PubMed]

44. Zhang, X.; Huang, X.; Zhang, Z.; Zhou, C.; Tian, J.; Zhao, W. Polarity variations of internal solitary waves over the continental shelf of the northern South China Sea: Impacts of seasonal stratification, mesoscale eddies and internal tides. J. Phys. Oceanogr. 2018, 48, 1349-1365. [CrossRef]

45. Gardner, W.D.; Southard, J.B.; Hollister, C.D. Sedimentation and resuspension in the western North Atlantic. Mar. Geol. 1985, 65, 199-242. [CrossRef]

46. Eittreim, S.; Thorndike, E.M.; Sullivan, L. Turbidity distribution in the Atlantic Ocean. Deep-Sea Res. 1976, 23, 1115-1127. [CrossRef]

47. Johnson, D.A.; McDowell, S.E.; Sullivan, L.G.; Biscaye, P.E. Abyssal hydrography, nephelometry, currents and benthic boundary layer structure in the Vema Channel. J. Geophys. Res. 1976, 81, 5771-5786. [CrossRef]

48. Gardner, W.D.; Sullivan, L.G. Benthic storms: Temporal variability in a deep ocean nepheloid layer. Science 1981, 213, 329-331. [CrossRef]

49. Pak, H. Fluctuations of beam-attenuation coefficient in the lowest $2 \mathrm{~m}$ on the continental rise off Nova Scotia. Mar. Geol. 1983, 51, 77-97. [CrossRef]

50. Pak, H.; Zaneveld, J.R.V. Temporal variations of beam attenuation coefficient on the continental rise off Nova Scotia. J. Geophys. Res. 1983, 88, 4427-4432. [CrossRef]

51. Hollister, C.D.; Nowell, A.R.M. HEBBLE epilogue. Mar. Geol. 1991, 99, 445-460. [CrossRef]

52. Isley, A.E.; Pillsbury, R.D.; Laine, E.P. The genesis and character of benthic turbid events, northern Hatteras Abyssal Plain. Deep-Sea Res. 1990, 37, 1099-1119. [CrossRef]

53. Klein, H.; Mittelstaedt, E. Currents and dispersion in the abyssal Northeast Atlantic: Results from the NOAMP field program. Deep-Sea Res. 1992, 39, 1727-1745. [CrossRef]

54. Richardson, M.J.; Weatherly, G.L.; Gardner, W.D. Benthic storms in the Argentine Basin. Deep-Sea Res. 1993, 40, 975-987. [CrossRef]

55. Gardner, W.D.; Tucholke, B.E.; Richardson, M.J.; Biscaye, P.E. Benthic storms, nepheloid layers, and linkage with upper ocean dynamics in the western North Atlantic. Mar. Geol. 2017, 385, 304-327. [CrossRef]

56. Tamburini, C.; Canals, M.; De Madron, X.D.; Houpert, L.; Lefèvre, D.; Martini, S.; D'Ortenzio, F.; Robert, A.; Testor, P.; Aguilar, J.A.; et al. Deep-sea bioluminescence blooms after dense water formation at the ocean surface. PLoS ONE 2013, 8, e67523. [CrossRef]

57. Puig, P.; Palanques, A.; Orange, D.L.; Lastras, G.; Canals, M. Dense shelf water cascades and sedimentary furrow formation in the Cap de Creus Canyon, northwestern Mediterranean Sea. Cont. Shelf Res. 2008, 28, 2017-2030. [CrossRef]

58. Johnson, D.R.; Weidemann, A.; Pegau, W.S. Internal tidal bores and bottom nepheloid layers. Cont. Shelf Res. 2001, 21, 1473-1484. [CrossRef]

59. Hosegood, P.; Bonnin, J.; van Haren, H. Solibore-induced sediment resuspension in the Faeroe-Shetland Channel: Solibores Above The Continental Slope. Geophys. Res. Lett. 2004, 31, 760-768. [CrossRef]

60. Palanques, A.; Puig, P.; Latasa, M.; Scharek, R. Deep sediment transport induced by storms and dense shelf-water cascading in the Northwestern Mediterranean basin. Deep. Sea Res. Part I 2009, 56, 425-434. [CrossRef]

61. Boegman, L.; Stastna, M. Sediment Resuspension and Transport by Internal Solitary Waves. Annu. Rev. Fluid Mech. 2019, 51, 129-154. [CrossRef]

62. Lorke, A.; Macintyre, S. The Benthic Boundary Layer (in Rivers, Lakes, and Reservoirs); Encyclopedia of Inland Waters; Academic Press: Oxford, UK, 2009; Volume 1, pp. 505-514. [CrossRef]

63. Carr, M.; Davies, P.A. Boundary layer flow beneath an internal solitary wave of elevation. Phys. Fluids 2010, 22, 026601. [CrossRef]

64. Aghsaee, P.; Boegman, L.; Diamessis, P.J.; Lamb, K.G. Boundary-layer-separation-driven vortex shedding beneath internal solitary waves of depression. J. Fluid Mech. 2012, 690, 321-344. [CrossRef] 
65. La Forgia, G.; Tokyay, T.; Adduce, C.; Constantinescu, G. Bed shear stress and sediment entrainment potential for breaking of internal solitary waves. Adv. Water Resour. 2020, 135, 103475. [CrossRef]

66. Jackson, C.R.; Silva, J.C.B.D.; Jeans, G. The Generation of Nonlinear Internal Waves. Oceanography 2012, 25, 927-941. [CrossRef]

67. Baker, E.T.; Hickey, B.M. Contemporary sedimentation processes in and around an active West Coast submarine canyon. Mar. Geol. 1986, 71, 15-34. [CrossRef]

68. Wang, B.; Bogucki, D.; Redekopp, L. Internal solitary waves in a structured thermocline with implications for resuspension and the formation of thin particle laden layers. J. Geophys. Res. 2001, 106, 9565-9585. [CrossRef]

69. Lien, R.-C.; Henyey, F.; Ma, B.; Yang, Y.J. Large-Amplitude Internal Solitary Waves Observed in the Northern South China Sea: Properties and Energetics. J. Phys. Oceanogr. 2014, 44, 1095-1115. [CrossRef]

70. Apel, J.R.; Holbrook, J.R.; Liu, A.K.; Tsai, J.J. The Sulu Sea internal soliton experiment. J. Phys. Oceanogr. 1985, $15,1625-1651$. [CrossRef]

71. Helfrich, K.R.; Melville, W.K. Long nonlinear internal waves. Annu. Rev. Fluid Mech. 2006, 38, 395-425. [CrossRef]

72. Shroyer, E.L.; Moum, J.N.; Nash, J.D. Vertical heat flux and lateral mass trans- port in nonlinear internal waves. Geophys. Res. Lett. 2010, 37, L08601. [CrossRef]

73. La Forgia, G.; Adduce, C.; Falcini, F. Laboratory investigation on internal solitary waves interacting with a uniform slope. Adv. Water Resour. 2017, 120, 4-18. [CrossRef]

74. Garrett, C. Internal tides and ocean mixing. Science 2003, 301, 1858-1859. [CrossRef] [PubMed]

75. Pedlowsky, J.; Miles, J. Waves in the ocean and atmosphere: Introduction to wave dynamics. Appl. Mech. Rev. 2004, 57, B20. [CrossRef]

76. Sutherland, B.R.; Barrett, K.J.; Ivey, G.N. Shoaling internal solitary waves. J. Geophys. Res. Ocean. 2013, 118, 4111-4124. [CrossRef]

77. Cacchione, D.; Wunsch, C. Experimental study of internal waves over a slope. J. Fluid Mech. 1974, 66, 223-239. [CrossRef]

78. De Silva, I.P.D.; Imberger, J.; Ivey, G.N. Localized mixing due to a breaking internal wave ray at a sloping bottom. J. Fluid Mech. 1997, 350, 1-27. [CrossRef]

79. Garrett, C. The role of secondary circulation in boundary mixing. J. Geophys. Res. 1990, 95, 3181-3188. [CrossRef]

80. Phillips, O.M.; Shyu, J.H.; Salmun, H. An experiment on boundary mixing: Mean circulation and transport rates. J. Fluid Mech. 1986, 173, 473-499. [CrossRef]

81. Garrett, C. Marginal mixing theories. Atmosphere-Ocean 1991, 29, 313-339. [CrossRef]

82. Morsilli, M.; Pomar, L. Internal waves vs. surface storm waves: A review on the origin of hummocky cross-stratification: Hummocky cross-stratification formed by internal waves. Terra Nova 2012, 24, 273-282. [CrossRef]

83. Tian, Z.; Zhang, S.; Guo, X.; Yu, L.; Jia, Y. Experimental investigation of sediment dynamics in response to breaking high-frequency internal solitary wave packets over a steep slope. J. Mar. Syst. 2019, 199, 103191. [CrossRef]

84. Lorenzoni, L.; Thunell, R.C.; Benitez-Nelson, C.R.; Hollander, D.; Martinez, N.; Tappa, E.; Varela, R.; Astor, Y.; Muller-Karger, F.E. The importance of subsurface nepheloid layers in transport and delivery of sediments to the eastern Cariaco Basin, Venezuela. Deep Sea Res. Part I 2009, 56, 2249-2262. [CrossRef]

85. Ribó, M.; Puig, P.; Salat, J.; Palanques, A. Nepheloid layer distribution in the Gulf of Valencia, northwestern Mediterranean. J Mar. Syst. 2013, 111-112, 130-138. [CrossRef]

86. Naudin, J.J.; Cauwet, G. Transfer mechanisms and biogeochemical implications in the bottom nepheloid layer. A case study of the coastal zone off the Rhone River (France). Deep. Sea Res. Part II 1997, 44, 551-575. [CrossRef]

87. Wainright, S. Stimulation of Heterotrophic Microplankton Production by Resuspended Marine Sediments. Science 1987, 238, 1710-1712. [CrossRef] [PubMed]

88. Wilson, A.M.; Raine, R.; Mohn, C.; White, M. Nepheloid layer distribution in the Whittard Canyon, NE Atlantic Margin. Mar. Geol. 2015, 367, 130-142. [CrossRef]

89. Stumpf, R.P.; Gelfenbaum, G.; Pennock, J.R. Wind and tidal forcing of a buoyant plume. Mob. Bay Ala. Cont. Shelf Res. 1993, 13, 1281-1301. [CrossRef]

90. Warrick, J.A.; Mertes, L.A.K.; Washburn, L.; Siegel, D.A. Dispersal forcing of southern California river plumes, based on field and remote sensing observations. Geo.-Mar. Lett. 2004, 24, 46-52. [CrossRef]

91. Kakoulaki, G.; MacDonald, D.; Horner-Devine, A.R. The role of wind in the near field and midfield of a river plume. Geophys. Res. Lett. 2014, 41, 5132-5138. [CrossRef]

92. Rong, Z.; Hetland, R.D.; Zhang, W.; Zhang, X. Current-wave interaction in the Mississippi-Atchafalaya river plume on the Texas-Louisiana shelf. Ocean Model. 2014, 84, 67-83. [CrossRef]

93. Halfman, B.M.; Johnson, T.C. Surface and Benthic Nepheloid Layers in the Western Arm of Lake Superior, 1983. J. Great Lakes Res. 1989, 15, 15-25. [CrossRef]

94. Geng, M.; Song, H.; Guan, Y.; Jun, C. Research on the distribution and characteristics of the nepheloid layers in the northern South China Sea by use of seismic oceanography method. Chin. J. Geophys. 2018, 61, 636-648. [CrossRef]

95. Helfrich, K.R. Internal solitary wave breaking and run-up on a uniform slope. J. Fluid Mech. 1992, 243, 133-154. [CrossRef]

96. Ivey, G.N. Nokes, R.I. Vertical mixing due to the breaking of critical internal waves on sloping boundaries. J. Fluid Mech. 1989, 204, 479-500. [CrossRef]

97. McPhee-Shaw, E.E. Kunze, E. Boundary layer intrusions from a sloping bottom: A mechanism for generating intermediate nepheloid layers. J. Geophys. Res. 2002, 107, 1-16. [CrossRef] 
98. Nakayama, K.; Imberger, J. Residual circulation due to internal waves shoaling on a slope. Limnol. Oceanogr. 2010, 55, 1009-1023. [CrossRef]

99. Tian, Z.; Jia, Y.; Du, Q.; Zhang, S.; Guo, X.; Tian, W.; Zhang, M.; Song, L. Shearing stress of shoaling internal solitary waves over the slope. Ocean Engineering 2021, 241, 110046. [CrossRef]

100. Arthur, R.; Fringer, O. Transport by breaking internal gravity waves on slopes. J. Fluid Mech. 2016, 789, 93-126. [CrossRef] 